\title{
High production dairy-beef cattle grazing systems: a review of research in the Manawatu
}

\author{
G.P. COSGROVE ${ }^{1}$, D.A. CLARK ${ }^{1}$ and M.G. LAMBERT ${ }^{1}$ \\ ${ }^{1}$ AgResearch, Grasslands Research Centre, PB 11008, Palmerston North \\ ${ }^{2}$ Dexcel, PB 3221, Hamilton \\ gerald.cosgrove@agresearch.co.nz
}

\section{Abstract}

During a span of 20 years, eight farmlet-scale experiments conducted in the Manawatu used a simple system of grazing management to maximise pasture growth and utilisation. Farmlets of 1.6 ha were stocked annually with 12 Friesian bulls ( 7.4 wintered/ ha) from early November at 3 months-of-age (70-80 $\mathrm{kg}$ liveweight (LW)) until slaughter during December - March at 16 - 19 months $(350-420 \mathrm{~kg} \mathrm{LW})$. The grazing management system involved seasonal adjustment in pasture spelling intervals, and an increase in grazing pressure in spring by addition of 3-month-old weaner bulls followed by the progressive removal of 'finished' animals during summer. With this control over feed supply and demand and the inherent capacity of growing bulls to cope with changes in feed availability, old permanent pasture producing approximately $13 \mathrm{t}$ dry matter/ha/yr was converted to approximately $1000 \mathrm{~kg} / \mathrm{ha} / \mathrm{yr}$ of net carcass weight gain. Using loafing pads in winter to reduce treading damage on wet soils and increase pasture utilisation and growth, increased annual LW gain (LWG)/ha by $2 \%$. Controlling the intensity of defoliation in summer through timely removal of bulls for slaughter increased average daily gain (ADG) during autumn and winter, but annual LWG/ha by only $1 \%$. Pastures renewed with improved cultivars and species produced more forage in summer (red clover), autumn (prairie grass) and winter, identified as periods of feed deficit for old permanent pastures. Strategic inputs of nitrogen $(\mathrm{N})$ fertiliser $(100 \mathrm{~kg} \mathrm{~N} / \mathrm{ha} / \mathrm{yr})$ in autumn or in spring on old permanent pasture, in conjunction with irrigation (approximately $250 \mathrm{~mm} /$ season) during November - March, and in combination with cool season active grasses, all increased annual meat output by up to $12 \%$ above that possible from old permanent pasture, by extending the duration of stocking in summer, increasing ADG, or a combination of both. While these gains are important, the studies highlighted the very high levels of output sustained from year-round all-grass grazing systems based on principles for maximising pasture growth and utilisation. Those high yields remain a benchmark in terms of the biological efficiency of growing and
\end{abstract}

converting pasture to animal product, although the economic optimum was at a lower stocking rate and level of output.

Keywords: dairy beef, grazing systems, liveweight gain, pasture utilisation

\section{Introduction}

In 1969 a series of systems-scale grazing experiments was commenced on the Manawatu plains by the late Dr Ray Brougham. These simple systems were designed to test principles of pasture growth and utilisation in realistic livestock systems based on the production of bull beef from dairy industry calves. Those principles related in particular to the spelling intervals and defoliation intensity required during different seasons of the year for maximum yields of ryegrass and consequences for the growth of associated legumes developed by Brougham and coworkers (see Harris 1996 for a review of this research and references therein), and to the effects of animals on pasture production e.g. treading damage (Edmond 1963).

This series of experiments tested whether the requirements of pastures could be integrated with the feed requirements of animals, demonstrated the production potential from efficient utilisation of pasture, and applied new solutions arising from basic research. They also served to extend these ideas directly to farmers, industry advisors/consultants, agribusiness, and scientists. Factors at the time that provided relevance and context for this research included the emerging export market for bull beef and the opportunity this presented for reducing wastage of dairy industry male calves, the high liveweight gain (LWG) and feed conversion efficiency of Friesian bulls, and the support from Government agencies, farmers, consultants and the science community for testing and developing pasture management principles within realistic livestock systems. This work contributed in part to the growth of an industry that in 2002 produced approximately $186000 \mathrm{t}$ carcass weight from 623000 bulls slaughtered, earning approximately $\$ 700 \mathrm{~m}$ p.a. in FOB export receipts (SONZAF 2002), and providing 
a viable alternative livestock system for many farmers.

This paper reviews the results of that research, and briefly discusses its contribution and significance to farming in the Manawatu. It is not intended to comprehensively present all data, but to summarise the main findings.

\section{Experimental methodology}

These experiments were conducted between 1969 and 1992 at the Aorangi research area near Palmerston North, on tile and mole drained recent alluvial soils (Rijkse \& Daly 1972). Eighteen-year means of weather at the site were $860 \mathrm{~mm}$ annual rainfall, 12.3 ${ }^{\circ} \mathrm{C}$ annual average $10-\mathrm{cm}$ soil temperature, and 17.6 ${ }^{\circ} \mathrm{C} / 8.0{ }^{\circ} \mathrm{C}$ annual average maximum and minimum air temperatures.

\section{Pastures}

These were old permanent mixed-species pastures, poorly developed in terms of species composition and containing a high proportion of browntop (Agrostis capillaris). From the outset of these trials, superphosphate $(9 \% \mathrm{P}, 11 \% \mathrm{~S})$ was applied annually in autumn at $250 \mathrm{~kg} / \mathrm{ha}$.

\section{Stocking and grazing management}

Farmlets of 1.62 ha were subdivided into 8 paddocks of 0.2 ha, and stocked annually in early November with 12 Friesian bull calves, 3-months old and 70-80 $\mathrm{kg}$ liveweight ( 7.4 bulls wintered/ha). Each farmlet was self-contained in terms of feed supply, and apart from the first study there was no conservation of pasture or feeding of supplements. The stocking rate was fixed for most periods of the year except from November to March when there were both weaner bulls and 15-month bulls on each farmlet. The exception to this pattern was the final experiment which compared stocking rates and grazing method (see experimental design). Animals were rotationally stocked in the 8-paddock system, in which both the spelling interval between successive grazings and the duration of stocking within paddocks varied seasonally (Table 1). Within paddocks, feed was rationed by strip-grazing in 1-2 day allocations during autumn and winter, with a maximum duration of stocking of eight days/paddock. Generally there were 8-9 grazing rotations per year. During November February, weaners grazed as 'leaders' and older bulls as 'followers' thereby extending the duration of stocking, and reducing the spelling interval within each grazing rotation during that period of the year. The only control over grazing pressure in this system was the addition of young animals in early November and removal of older bulls during summer. Bulls were progressively removed (generally, heaviest first) in sufficient numbers to maintain average daily gain (ADG) in remaining bulls at or above $0.4 \mathrm{~kg} / \mathrm{hd} / \mathrm{day}$, taking into account current and anticipated pasture growth rates. Paddocks within farmlets were mowed after grazing, generally for 1 grazing rotation during November or early December, to remove uneaten reproductive stem material.

\section{Animal management}

Calves were vaccinated against salmonella, leptospirosis and clostridial diseases. Other inputs for animal health were confined to regular anthelmintic drenches, and treatments for controlling external parasites, using products commercially available at the time. Pastures were sprayed with paraffin oil to control bloat, mainly during the period August November. Ryegrass staggers was prevalent during summer-autumn in all trials in weaners, and to a lesser extent in 15-19 month bulls. Other than care in moving and handling, no precautions or treatments were imposed to manage staggers.

\section{Experimental design}

The experimental unit was a farmlet, and each experiment was conducted using six farmlets. For the first two experiments there were two treatments with three replications of each (with one exception where there were four replicates of new pastures and two replicates of the control). For subsequent experiments there were three treatments each with two replicates. Eight studies, each of three years duration were conducted. For each experiment the control treatment consisted of replicate farmlets of old permanent pasture, managed as described above. Specific treatments applied in the eight studies are described below. Winter loafing pads (Experiment 1) During wet weather the rising-yearling bulls were removed from pasture after 4-8 hours of grazing and held for 1620 hours overnight on a loafing pad to 
reduce treading damage. This applied on average for 36 days each winter/spring.

Summer over-grazing (Experiment 2)

To determine the importance of controlling the intensity of grazing in summer, 15-month old bulls were deliberately retained for approximately 1 month longer than their cohorts on the control farmlets, to increase the grazing pressure during summer.

$N$ fertiliser (Experiment 3 )

Two treatments, having different timing of applications were compared against the control. Urea $(46 \% \mathrm{~N})$ was applied across the whole farmlet at 50 $\mathrm{kg} \mathrm{N} / \mathrm{ha}$ in both April and July (treatment 1) or in July and November (treatment 2) i.e. $100 \mathrm{~kg} \mathrm{~N} / \mathrm{ha} / \mathrm{yr}$ in total for each treatment.

$N+$ irrigation (Experiment 4)

$\mathrm{N}$ fertiliser (April/July; treatment 1 ) and $\mathrm{N}$ plus irrigation (treatment 2), each as described above, were applied in combination. Spray irrigation was applied at $50 \mathrm{~mm}$ when the deficit, calculated according to a soil moisture deficit model based on daily pan evaporation, reached $50 \mathrm{~mm}$. This required approximately $250 \mathrm{~mm}$ between late November and early April.

Alternative pasture mixtures (Experiment 5)

New pastures comprised of perennial ryegrass (Lolium perenne, cv 'Nui'), tetraploid hybrid ryegrass (Lolium $x$ boucheanum, cv 'Greenstone'), white clover (Trifolium repens, cv 'Pitau'), and red clover (Trifolium pratense, cv 'Pawera') were sown into cultivated seedbeds across the entire area of each farmlet allocated to this treatment in autumn and grazed intermittently by sheep during establishment over the winter and spring. In November pasture mass was equilibrated with that available on control farmlets, and stocked with experimental weaners and older bulls as required to simulate the normal summer stocking.

Species + irrigation (Experiment 6)

New pastures composed of perennial and hybrid ryegrasses, red clover and white clover were established as described above on four farmlets (treatment 1). Two of these four farmlets received irrigation (treatment 2) as described above.

Species + irrigation $+N$ (Experiment 7)

New pastures comprised of perennial ryegrass, prairie grass ( Brom us wildenowii, cv 'Matua'), red clover and white clover (treatment 1), with two of the four farmlets receiving additional inputs of $100 \mathrm{~kg} \mathrm{~N} / \mathrm{ha} /$ $\operatorname{yr}(50 \mathrm{~kg} \mathrm{~N}$ in April and July) and irrigation (treatment 2) as described above.

Stocking rate and grazing method (Experiment 8)

Three fixed stocking rates $(7.4,5.0$ and 2.5 bulls wintered/ha; control, treatment 1 and treatment 2 , respectively) were compared using the rotational stocking system, and at a single stocking rate of 5.0/ ha, the rotational stocking system was compared with continuous stocking (treatment 4).

\section{Measurements}

Bulls were weighed at three-weekly intervals, after fasting overnight for 16 hours. Carcass weight of animals at slaughter was recorded. While the cumulative LWG for each generation of bulls accrued over 12-16 months, this output occurred annually and is considered here as annual production. Pasture measurements were made to simulate the quantity of pasture being consumed by cattle. In three paddocks of each farmlet three exclusion cages, which prevented removal of forage during grazing, were cut immediately after bulls finished grazing that paddock, to the same height as the post-grazing residual, to simulate the dry matter (DM) removed during grazing. Cages were then randomly relocated to previously grazed areas for the next regrowth cycle. These measurements were thus aligned with the frequency of grazing each paddock and, by simulating pasture removed during each grazing, were considered to be an estimate of total annual DM intake. A composite subsample was dried at $80{ }^{\circ} \mathrm{C}$ for 24 hours to determine DM yield and a further subsample was separated into ryegrass, white clover, red clover and prairie grass if present, and other grasses, weeds and dead material.

\section{Data handling and presentation}

The data reviewed are drawn from the various publications cited, and from an internal report (Rumball 1990). No statistical analyses have been conducted specifically for this review and readers are referred to the individual publications for more comprehensive results and analyses.

\section{Results and discussion \\ Annual animal production}

Averaged over 16 years of measurements the mean annual LWG from the control farmlets was $2000 \mathrm{~kg}$ / ha. Average daily gain during these years was 0.63 $\mathrm{kg} / \mathrm{hd} / \mathrm{day}$, and in these systems bulls required on average $6.9 \mathrm{~kg}$ DM per $\mathrm{kg}$ of LWG (Clark \& Brougham 1979). The range in annual production was from $1775 \mathrm{~kg} \mathrm{LWG} / \mathrm{ha}$ to $2260 \mathrm{~kg} \mathrm{LWG} / \mathrm{ha}$ and the coefficient of year-to-year variation in annual LWG/ ha was $8 \%$. The dressing \% (carcass weight as a proportion of fasted LW) of bulls killed at 350-420 $\mathrm{kg} \mathrm{LW}$ at 16-19 months of age ranged from $46 \%$ to $50 \%$, translating to a net annual hot carcass yield of $960 \mathrm{~kg} / \mathrm{ha} / \mathrm{yr}$. Comparable trials conducted during 2 
years at Rukuhia, using cryptorchid Friesians stocked at $4.85 / \mathrm{ha}$ produced $920 \mathrm{~kg}$ hot carcass/ha/yr (Croy \& Weeda 1974; Weeda \& During 1974).

\section{Seasonal production}

The mean ADG was lowest in winter $(0.2 \mathrm{~kg} / \mathrm{hd} /$ day $)$ and highest in spring $(1.2 \mathrm{~kg} / \mathrm{hd} /$ day; Table 2$)$, although peak growth rates of $1.6 \mathrm{~kg} / \mathrm{hd} /$ day were sustained for 3 to 6 weeks during October and early November. Year-to-year variability in ADG (over 11 years) was greatest in winter (CV 86\%) and lowest in spring and summer (CV 16-17\%).

Table 2 Long-term means of average daily gains (ADG, $\mathrm{kg} / \mathrm{hd} / \mathrm{day}$ ) during each of four seasons and year-to-year coefficient of variation (CV) in these means for bulls stocked on old permanent pasture (control) farmlets.

\begin{tabular}{lcc}
\hline & \multicolumn{2}{c}{ Average daily gain } \\
Season & Mean & CV \\
\hline Autumn (March-May) & 0.36 & $30 \%$ \\
Winter (June-August) & 0.2 & $86 \%$ \\
Spring (Sept-November) & 1.2 & $17 \%$ \\
Summer (Dec-February) & 0.66 & $16 \%$ \\
\hline
\end{tabular}

\section{Effect of changes in grazing management}

Using loafing pads to reduce treading damage on wet soils in winter and ear ly spring increased annual LWG/ ha by $2 \%$ (Brougham et al. 1975; Table 3). These pads were of marginal value because ryegrass and white clover have a relatively high tolerance of treading damage (Edmond 1964) and recover from short-term damage and because bulls were able to compensate for brief periods of under-feeding resulting when treading suppressed pasture production. In intensive rotational stocking systems with high daily stock densities, treading on wet soils may suppress utilisation and regrowth, but the proportion of area affected is often low e.g. the proportion of area allocated on a single day in late winter was only $3 \%$. A slight reduction in pasture yield during summer, autumn and winter on the systems using a loafing pad (14.7 vs $15.1 \mathrm{t} \mathrm{DM/ha/yr)} \mathrm{was}$ offset by higher production of white clover in all seasons except autumn (2.1 vs 1.9 t DM/ha/yr).

Deliberately “over-grazing” pastures during summer (as for example may occur during droughts, or when other factors cause excessive grazing pressure) by retaining 'finished' stock for an extra 26 days on average, marginally reduced annual LWG/ ha (Table 3). However, there were larger short-term effects and ADG was reduced in summer by $13 \%$ ( 0.53 vs $0.61 \mathrm{~kg} / \mathrm{hd} /$ day) and by $33 \%$ in autumn $(0.22$ vs $0.32 \mathrm{~kg} / \mathrm{hd} /$ day), but these reductions were offset by higher ADG in spring (1.15 vs $1.05 \mathrm{~kg} / \mathrm{hd} /$ day). Both of these early experiments highlighted the resilience in annual production from well managed grazing systems on well drained, heavy textured soils in this environment to short-term perturbations in ADG. This ability to recover may be greater for these bull-beef systems on naturally fertile, well-drained soils, than for systems in more extreme environments, or where under feeding of cows in summer and autumn, for example, may affect both current and subsequent lactation yields.

\section{Strategic $\mathbf{N}$ fertiliser}

Applying $50 \mathrm{~kg} \mathrm{~N} / \mathrm{ha}$ in July and November increased annual LWG/ha by $7 \%$, compared with $1-3 \%$ (the range in consecutive, 3-yr trials) when applied at the same rate in April and July (Table 3). The response efficiency was 1.3 and $0.6 \mathrm{~kg} \mathrm{LWG} / \mathrm{kg} \mathrm{N}$ applied, respectively, for the July/November and April/July applications. Boosts to ADG were greatest in autumn

Table 3 Mean annual liveweight gain (LWG kg/ha) and duration of stocking (days from input of weaner bulls each November until slaughter) for treatments within 4 experiments each of 3 or 4 years duration. See text for description of the treatment(s) used in each experiment. The percentage change in annual LWG/ha for each treatment relative to the control is shown in brackets.

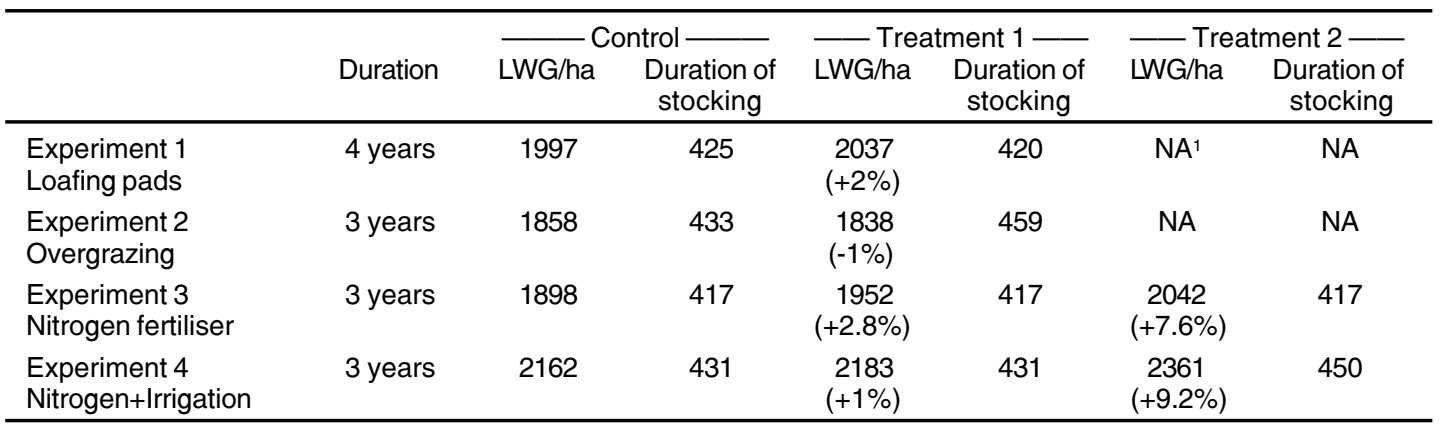

${ }^{1} \mathrm{NA}=$ Not Applicable to that particular experiment. 
Table 4 Mean annual liveweight gain (LWG kg/ha) and duration of stocking (days from input of weaner bulls each November until slaughter) for treatments within 4 experiments, each of 3 years duration. See text for description of the treatment(s) used in each experiment. The percentage change in annual LWG/ha for each treatment relative to the control is shown in brackets.

\begin{tabular}{|c|c|c|c|c|c|c|c|c|}
\hline & \multicolumn{2}{|c|}{ — Control } & \multicolumn{2}{|c|}{ — Treatment $1 \longrightarrow$} & \multicolumn{2}{|c|}{ — Treatment $2-$} & \multicolumn{2}{|c|}{ — Treatment $3-$} \\
\hline & LWG/ha & $\begin{array}{l}\text { Duration of } \\
\text { stocking }\end{array}$ & LWG/ha & $\begin{array}{l}\text { Duration of } \\
\text { stocking }\end{array}$ & LWG/ha & $\begin{array}{l}\text { Duration of } \\
\text { stocking }\end{array}$ & LWG/ha & $\begin{array}{l}\text { Duration of } \\
\text { stocking }\end{array}$ \\
\hline $\begin{array}{l}\text { Experiment } 5 \\
\text { New pasture (NP) }\end{array}$ & 1761 & 418 & $\begin{array}{c}1965 \\
(+12 \%)\end{array}$ & 418 & $\mathrm{NA}^{1}$ & NA & NA & NA \\
\hline $\begin{array}{l}\text { Experiment } 6 \\
\text { NP + irrigation (irrig) }\end{array}$ & 1945 & 426 & $\begin{array}{c}2145 \\
(+10 \%)\end{array}$ & 430 & $\begin{array}{c}2221 \\
(+11.4 \%)\end{array}$ & 441 & NA & NA \\
\hline $\begin{array}{l}\text { Experiment } 7 \\
\mathrm{NP}+\text { irrig. }+\mathrm{N}\end{array}$ & 1882 & 426 & $\begin{array}{c}1871 \\
(-1 \%)\end{array}$ & 431 & $\begin{array}{c}1969 \\
(+5 \%)\end{array}$ & 441 & NA & NA \\
\hline $\begin{array}{l}\text { Experiment } 8 \\
\text { Stocking rate \& } \\
\text { grazing method }\end{array}$ & 1805 & 420 & $\begin{array}{c}1740 \\
(-3.6 \%)\end{array}$ & 450 & $\begin{array}{c}1116 \\
(-38 \%)\end{array}$ & 480 & $\begin{array}{c}1612 \\
(-11 \%)\end{array}$ & 540 \\
\hline
\end{tabular}

$(0.47 \mathrm{~kg} / \mathrm{hd} /$ day for $\mathrm{N}$ fertilised vs $0.39 \mathrm{~kg} / \mathrm{hd} / \mathrm{day}$ for control) and in spring (1.0 vs $0.9 \mathrm{~kg} / \mathrm{hd} /$ day), for the April/July and July/November applications, respectively. Application in July/November suppressed clover yield by $8 \%$, compared with $24 \%$ when applied in April/July, and increased ryegrass yield by $12 \%$ and $7 \%$ for the 2 application times, respectively. Nitrogen fixation was reduced from 100 $\mathrm{kg} \mathrm{N} / \mathrm{ha} / \mathrm{yr}$ to $70 \mathrm{~kg} \mathrm{~N} / \mathrm{ha} / \mathrm{yr}$ by both the April/July and the July/November application of fertiliser $\mathrm{N}$ (Crush et al. 1982).

\section{Irrigation}

Irrigation applied to old permanent pasture increased annual LWG/ha by $8.2 \%$ (Table 3 ), and by $1.4 \%$ when applied to ryegrass/red and white clover pastures (Table 4), extending the time older bulls could be supported through summer by 19 days and 11 days, respectively. Weeda \& During (1974) recorded 3.8\% higher LWG/ha/yr when $30 \%$ of the farmlet area was irrigated, and Hutton (1978) recorded 22\% higher milkfat per ha and per cow, when $460 \mathrm{~mm}$ of irrigation was applied annually. The response in ADG was greatest in autumn $(0.5 \mathrm{~kg} / \mathrm{hd} /$ day vs $0.36 \mathrm{~kg} / \mathrm{hd}$ day) partially offset by a reduction in ADG in spring of $4 \%$. Irrigation increased annual DM yield by $2.0 \mathrm{t}$ $\mathrm{DM} / \mathrm{ha} / \mathrm{yr}$, comprised of an additional $1.2 \mathrm{t} \mathrm{DM} / \mathrm{ha} / \mathrm{yr}$ of ryegrass $(7.5 \%)$ and $0.8 \mathrm{t} \mathrm{DM} / \mathrm{ha} / \mathrm{yr}$ of white clover $(22 \%)$. Irrigation and nitrogen fertiliser applied to prairie grass pasture (expt 7, Table 4) increased annual $\mathrm{DM}$ production by $3.0 \mathrm{t} \mathrm{DM} / \mathrm{ha}(15 \%)$ to $16.8 \mathrm{t} \mathrm{DM} /$ ha/yr, but annual LWG/ha by only $5 \%$, because the higher carrying capacity and duration of stocking in summer was partially offset by lower ADG.

\section{Pasture species and cultivars}

New pastures comprised of perennial and hybrid ryegrasses, white and red clovers increased annual LWG/ha by $12 \%$ and $10 \%$, respectively, in consecutive 3-year studies (Table 4). Red clover produced approximately $2.4 \mathrm{t} \mathrm{DM} / \mathrm{ha} / \mathrm{yr}$, or $17 \%$ of total annual DM production. These new pastures contained $30 \%$ clover (red plus white) and boosted ADG in summer ( $0.65 \mathrm{vs} 0.59 \mathrm{~kg} / \mathrm{hd} /$ day) and autumn ( 0.53 vs $0.38 \mathrm{~kg} / \mathrm{hd} /$ day), compared with old pasture which contained on average $14 \%$ white clover. They also fixed approximately $25 \%$ more nitrogen than in the old pasture control farmlets $(105 \mathrm{~kg} \mathrm{~N} / \mathrm{ha} / \mathrm{yr}$ vs $85 \mathrm{~kg} \mathrm{~N} / \mathrm{ha} / \mathrm{yr}$; Crush et al. 1983). However the benefits for ADG of more clover during summer and autumn were partially offset by lower ADG in winter $(0.15 \mathrm{vs} 0.23)$ and in spring ( $1.0 \mathrm{vs} 1.1 \mathrm{~kg} / \mathrm{hd} / \mathrm{day})$ because red clover dominance suppressed ryegrass production. Increased frequency of grazing in summer controlled this dominance and improved the balance of red clover and ryegrass and seasonal distribution of DM production (Cosgrove \& Brougham 1985). Including prairie grass in the mixture also controlled the dominance of red clover and maintained high DM production in summer, autumn and early-winter, but again the low proportion of ryegrass and the inherent slow early-spring growth of prairie grass limited production in spring. Average daily gains by weaners on prairie grass pastures were $18 \%$ lower during summer and autumn than on ryegrass white clover pastures despite ad libitum feeding, and despite in vitro digestibility and mineral content being similar to ryegrass (Crush et al. 1989). However, this mixture supported higher carrying capacity of 15-month bulls during summer (Cosgrove \& Brougham 1988), partially compensating for the lower ADG of weaners. The production benefits of new pastures related more to the inclusion of red clover and subsequently prairie grass, than to superior 
ryegrass and white clover cultivars. However, this comparison is relevant to farmers because the choice they often face is to either retain the existing pasture or if renewing, then to use the best species and cultivars available.

\section{Stocking rate and grazing method}

Annual LWG/ha was $3.5 \%$ greater from systems stocked at 7.4/ha compared with 5.0 /ha, and $38 \%$ greater than systems stocked at 2.5/ha (Clark 1992; Table 4), consistent with many studies indicating the dominant influence of stocking rate on grazing system productivity (McMeekan \& Walshe 1964; Matches $\&$ Burns 1985). In the study by Clark (1992) rotational stocking at $5.0 \mathrm{bulls} / \mathrm{ha}$ resulted in $7 \%$ higher LWG/ha than continuous stocking, also at 5.0 bulls/ha. This was similar to the average superiority of $5 \%$ in studies reviewed by Marsh (1975), and 6\% reported by Ernst et al. (1980) for ryegrass pastures in temperate environments, but much less than the $40 \%$ superiority at 6.2 steers/ha reported by Conway (1963). Farmers opinion that 7.4 /ha was too high a stocking rate for maximum economic output was validated in this study, and the highest gross margin (gross revenue less costs of replacement calves, interest and operating expenses) resulted at the intermediate stocking rate, as in most studies of this type (Riewe 1981).

\section{General discussion}

High in-situ utilisation of pasture grown and its efficient conversion to $\mathrm{LWG} / \mathrm{ha}$, resulted in sustained high yields of nearly $1000 \mathrm{~kg}$ net carcass gain per ha per year. These systems demonstrated that high yields are possible from old permanent pasture, with low inputs of fertiliser, labour and capital for infrastructure such as fencing and water supply. Annual total yield of animal product was remarkably consistent despite year-to-year variation in the seasonal distribution of production. This consistency in annual yield is due in part to the comparative flexibility of growing bulls, compared with breeding/lactating animals where failure to meet feed requirements during critical periods may result in prolonged effects on performance. The management system used fixed stocking from March - November and variable stocking from November - March. An underlying assumption in using a single, fixed stocking rate was that the restriction on DM intake and ADG at the very high stocking rate would ensure that increases in pasture supply during March - November resulting from pasture treatments would be converted to additional ADG without the need for variable stocking. For example, in the first two years of operation of these systems conservation of "surplus" pasture in spring restricted DM intake and ADG, and this loss outweighed the gains from supplementary feeding of this conserved pasture in winter.

\section{Aligning feed demand with supply}

Several aspects of the management system facilitated the alignment of a seasonally variable feed supply with feed demand that increased progressively as bulls grew from 3 to 16 months-of-age, to enable yearround all-grass feeding. During autumn, long spelling intervals were used to maximise pasture accumulation, coupled with restricted feed allocation, and the relatively low demand of 6-8-month old bulls. Drawing on these accumulated reserves allowed for feed consumption during winter to exceed pasture growth and ADG to be maintained. The high stocking rate and the capacity of Friesian yearling bulls for high intake and efficient conversion to LWG enabled full in situ utilisation of the high pasture growth rates in spring. An increase in grazing pressure at the peak of pasture growth rate followed by progressive reductions as increasing soil moisture deficits and ambient temperature restricted grass growth in summer, matched animal demands with feed supply.

\section{Pasture growth and composition}

The intensive rotational stocking system promoted the desirable pasture species, ryegrass and white clover, and suppressed the abundance of less desirable grasses such as browntop. Total annual DM yields ranged from 13 - $15.5 \mathrm{t} \mathrm{DM} / \mathrm{ha} / \mathrm{yr}$ (Cosgrove \& Brougham 1988). Ryegrass and white clover contributed about $80 \%$ of total DM production, and the seasonal distribution of production reflected this composition, with rapid growth in spring but feed deficits in winter and summer. Extra DM produced by nitrogen fertiliser, red clover pastures and irrigation generally translated to higher ADG and increased LWG/ha with feed conversion efficiency similar to that recorded by Clark \& Brougham (1979). The exception to this was the low ADG of weaner bulls on prairie grass pastures during summer. However, gains from experimental inputs during some seasons were partially offset by reductions at other times of the year, highlighting the stability in productivity of the unmodified, old permanent pasture systems. These reductions were due in part to inputs having greater effect on seasonal distribution of DM production than in total DM production, and to the self-limiting effect that higher ADG imposed for subsequent maintenance feed requirements. In general, gains made by bulls closer to marketing (as higher ADG and/or increased duration of stocking) were more readily captured as 
increased annual LWG/ha than were gains made by young er animals (higher ADG).

\section{Industry uptake}

A major feature of these studies was the application of simple principles for maximising pasture growth and utilisation of pasture to achieve very high animal production. These principles have been adopted and applied by farmers in a variety of ways (e.g. Guy 1977) and refined by evaluations in larger-scale studies (e.g. McRae 1987). For example, the use of continuous stocking systems reduced stock density and the damage to pastures and fencing that occurred when large mobs of bulls were rotationally stocked. Many farmers imposed variable stocking through buying/selling strategies to match animal demand with pasture supply, using skills in trading stock in preference to the careful control of rotation lengths necessary in a fixed stocking system. Technograzing ${ }^{\mathrm{TM}}$ systems (Charlton \& Wier 2001) enable farmers to rotationally stock large numbers of animals in practical, low-labour systems, while also keeping the size of individual mobs small to improve animal behaviour. Profitability is strongly influenced by the purchase price of replacements, the largest variable cost. This, and the grading/price structure for bull beef encourages risk-averse farmers to adopt lower stocking rates (lower capital requirements) and to place more emphasis on margins per animal and per hectare, than on production per hectare. However, the goals of high utilisation of pasture and efficient conversion to animal product are common to all systems.

\section{ACKNOWLEDGEMENTS}

The late Dr Ray Brougham designed and initiated this series of studies. Dr John Rumball collated and summarised much of the data, including unpublished data. The late Don Johnston contributed to this work in his role as Dairy Board Consulting Officer, and Dr Don Causley was involved as a scientist. D. McDougall, S. Crotty, T. Cooper, M. Whitcombe, J. McMillan, L.E. Madgwick, G.P. Owens, R.G.C. Maxwell, J.S. Cudby, W.J. Thomas and C.B. Anderson provided technical expertise during the conduct of these trials.

\section{REFERENCES}

Brougham, R.W.; Causley, D.C.; Madgwick, L.E. 1975. Pasture management systems and animal production. Proceedings of the Ruakura Farmers Conference 27: 65-69.

Brougham, R.W.; Cosgrove, G.P. 1985. Pastures and pasture management for high animal production in New Zealand. Proceedings of the $X V$ International Grassland Congress. 1134-1136.

Charlton, J.F.L.; Wier, J.H. 2001. TechnoGrazing ${ }^{\mathrm{TM}}$ a new grazing concept. Proceedings of the New Zealand Grassland Association 63: 33-36.

Clark, D.A.; Brougham, R.W. 1979. Feed intake of grazing Freisian bulls. Proceedings of the New Zealand Society of Animal Production 39: 265274.

Clark, D.A. 1992. The effect of stocking rate on bull beef production. Dairyfarming Annual 44: 15-20.

Conway, A. 1963. Effect of grazing management on beef production. II. Comparison of three stocking rates under two systems of grazing. Irish Journal of Agricultural Research 2: 243-258.

Cosgrove, G.P.; Brougham, R.W. 1985. Grazing management influences on seasonality and performance of ryegrass and red clover in a mixture. Proceedings of the New Zealand Grassland Association 46:71-76.

Cosgrove, G.P.; Brougham, R.W. 1988. Pasture strategies for dairy-beef production. Proceedings of the New Zealand Grassland Association 49: 57-62.

Croy, B.G.; Weeda, W.C. 1974. Beef production on pasture and lucerne. Proceedings of the New Zealand Grassland Association 35: 73-79.

Crush, J.R.; Cosgrove, G.P.; Brougham, R.W. 1982. The effect on nitrogen fertiliser on clover nitrogen fixation in an intensively grazed Manawatu pasture. New Zealand Journal of Experimental Agriculture 10: 395-399.

Crush, J.R.; Cosgrove, G.P.; Brougham, R.W. 1983. Nitrogen fixation during $1979-81$ in 2 pastures on the Manawatu Plains. New Zealand Journal of Experimental Agriculture 11: 17-20.

Crush, J.R.; Evans, J.P.M.; Cosgrove, G.P. 1989. Chemical composition of ryegrass and prairie grass pastures. New Zealand Journal of Agricultural Research 32: 461-468.

Edmond, D.B. 1963. Effects of treading perennial ryegrass and white clover pastures in winter and summer at 2 soil moisture levels. New Zealand Journal of Agricultural Research 6: 265-276.

Edmond, D.B. 1964. Some effects of sheep treading on the growth of 10 pasture species. New Zealand Journal of Agricultural Research 7: 1-16.

Ernst, P.; Le Du, Y.L.P.; Carlier, L. 1980. Animal and sward production under rotational and continuous grazing management - a critical appraisal. pp. 119126. In: The role of nitrogen in intensive grassland production. Eds. Prins, W.H.; Arnold, G.H. Pudoc, Wageningen, The Netherlands.

Guy, M. 1977. The maximum utilisation of pasture 
with intensive livestock production. Proceedings of the New Zealand Grassland Association 39(1): 38-44.

Harris, W. 1996. The contributions of Dr Raymond Wilkie Brougham to grassland science and management. Proceedings of the New Zealand Grassland Association 58: 23-48.

Hutton, J.B. 1978. Dairy cattle management. Proceedings of the Ruakura Farmers Conference 30: FPP 167.

Marsh, R. 1975. Systems of grazing management for beef cattle. pp. 119-128. In: Pasture utilisation by the grazing animal. Eds. Hodgson, J.; Jackson, D.K. Occasional Symposium No. 8. British Grassland Society.

Matches, A.G.; Bums, J.C. 1985. Systems of grazing management. pp 537-547. In: Forages: the science of grassland agriculture. Eds. Heath, M.E.; Barnes, R.F.; Metcalf, D.S. Iowa State University Press, Ames, Iowa.

McMeekan, C.P.; Walshe, M.J. 1964. The interrelationship of grazing method and stocking rate in the efficiency of pasture utilisation by grazing dairy cattle. Journal of Agricultural Science 61: 143-167.

McRae, A.F. 1987. Tuapaka Beef Unit: Seasons three and four (and a new direction). Tuapaka Farm Series Publication No. 4. Massey University, Palmerston North. 52 pp.

Riewe, M.E. 1981. The economics of grazing. pp 517-526. In: Forage evaluation: concepts and techniques. Eds. J.L. Wheeler; R.D. Mochrie. American Forage and Grassland Council.

Rijkse, W.C.; Daly, B.K. 1972. Soils of Aorangi experimental farm, Manawatu district. New Zealand Journal of Agricultural Research 15: 117-136.

Rumball, J. 1990. Aorangi dairy beef research - A summary. Internal report. Grasslands Division, DSIR. 22 pp.

SONZAF, 2002. Situation and outlook for New Zealand Agriculture and Forestry. Ministry of Agriculture and Forestry, Wellington.

Weeda, W.C.; During, C. 1974. Sprinkler irrigation of pasture for dairy beef bulls. Proceedings of the New Zealand Grassland Association 41: 54-61. 